\title{
THE ASSESSMENT OF COMPETITIVENESS IN THE CASE OF LATVIA AND LITHUANIA
}

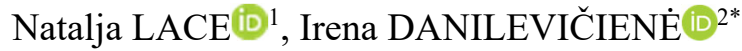 \\ ${ }^{1}$ Riga Technical University, 6 Kalnciema str., LV-1048, Riga, Latvia \\ ${ }^{2}$ Department of Financial Engineering, Faculty of Business Management, \\ Vilnius Gediminas Technical University, Saulètekio al. 11, LT-10223, Vilnius, Lithuania \\ *E-mail: irena.danileviciene@vgtu.lt
}

\begin{abstract}
Purpose - the purpose of the article is to reveal and to assess the factors of the industry's competitiveness.
Research methodology - to achieve the aim of the article the total factor productivity, return on equity and comparative analysis methods are used.

Findings - the most productive sectors in Lithuania are mining and quarrying; electricity, gas, steam and air conditioning supply; water supply, sewerage, waste management and remediation activities; manufacturing. It follows, that companies at mentioned sectors are working productively and purposefully use its equity. In Latvia, the most productive industry is financial and insurance activities, where earns in comparison with the total shareholder's equity invested in it are greater.

Research limitations - in this article the following research limitations are applied: here are analyzed the data of the 2007-2017 y. y. using total factor productivity and return on equity methods. Also here should be included the space limitation (here are analyzed the Latvia and Lithuania cases).

Practical implications - the improvement of the industry's competitiveness is possible due to the targeted management of the main productivity factors: labour and capital.

Originality/Value - productivity is based on the maintenance of the industry's productivity due to the proper use of the production factors to create value-added. Also, are analyzed the relation between total factor productivity and return on equity.
\end{abstract}

Keywords: capital, competitiveness, labour, return on equity, total factor productivity.

JEL Classification: D24, E24, J24, O47.

Conference topic: Contemporary Financial Management.

\section{Introduction}

Competitiveness is the driving force of objects and market players which encourages them to be better than others. The competitive position and the assessment of the competitiveness of companies and country's becomes one of the most important issues for every economist. Competitiveness is often seen as a broader category that defines productivity, profitability and uniqueness of the companies. The concept of competitiveness which follows from the results of comparative economic research emerged and developed in the United States at the end of the 20th century (Lotfi \& Karim, 2016). There was an opinion that only competitive companies can survive in the market and adequately meet the needs of consumers, even with strong internal and external influences and the need to efficiently utilize available resources to maximize future returns. There are many ways to compete with each other (for example the quality of the product, the application of new working methods and innovative technologies, the duration of the delivery time), so there is a need for the further explanation of how the competitiveness of industries should be assessed using different valuation methods.

The main object of the article is the industry's competitiveness and its factors, the purpose is to reveal and assess them. The assessment of the industry's competitiveness is done by using the total factor productivity, return on equity and comparative analysis methods. Also, using the above-mentioned methods at this article the following research limitations are applied: here are analysed the data of the 2007-2017 y. y. using total factor productivity and return on

(C) 2019 Authors. Published by VGTU Press. This is an open-access article distributed under the terms of the Creative Commons Attribution (http://creativecommons.org/licenses/by/4.0/) License, which permits unrestricted use, distribution, and reproduction in any medium, provided the original author and source are credited. 
equity methods. Here should be included the space limitation (here are analysed the two of all Baltic states - Latvia and Lithuania - cases).

The results of deeper researches have shown that the most productive sectors in Lithuania are mining and quarrying; electricity, gas, steam and air conditioning supply; water supply, sewerage, waste management and remediation activities; manufacturing. It follows, that companies at mentioned sectors are working productively and purposefully use its equity. In Latvia, the most productive industry is financial and insurance activities, where earns in comparison with the total shareholder's equity invested in it are greater.

It follows, that the targeted management of the main productivity factors: labour and capital leads to the improvement of the industry's competitiveness. The proper use of the production factors and the creation of value-added is the base of the industry's productivity. Also, it is necessary to mention, that productivity can be analysed using different methods, but here are distinguished two main methods: total factor productivity and return on equity.

\section{The concept of competitiveness and its features}

One of the key challenges facing businesses is fostering economic development, which is closely related to the country's ability to remain competitive, to make the best use of its existing workforce and capital and to ensure profit growth. It follows that competitiveness is one of the key factors affecting economic development. These effects are possible using certain transmission channels, which are manifested as aspects of competitiveness.

In general terms, competitiveness is the ability to deliver services and products to the market in a timely, appropriate place and form, requiring customers to pay an appropriate price that is lower than of their competitors but covers the costs of production (Lotfi \& Karim, 2016; Bondarenko, Liganenko, Kalaman, \& Niekrasova, 2018). So, in this way competitiveness is understood as "the ability of certain firms to earn, lead and compete with others for better performance, faster work, productive, quality and innovative working methods (Meilienė \& Snieška, 2010; Bruneckienė \& Kilijoniené, 2011; Wychowanek, 2015; Yordan, Nasution \& Buang, 2017) and to gain a larger market share (Schwab \& Porter, 2007)".

On the other hand, the concept of competitiveness is associated with ,the ability to maintain high (sustainable) living standards of workers, provided that they are able to create a high-quality product and maintain an adequate level of product quality (Croes, 2011; Abreu-Novais, Ruhanen \& Arcodia, 2016; Ramlawati \& Kusuma Putra, 2018)“. In this point of view, stable economic growth creates the conditions for fostering the welfare of the population (Tarkowski, Palmowski, Kopeć \& Wendt, 2016).

The OECD competitiveness is defined as ,the ability to pursue international competition at various levels (enterprises, industries, regions, countries or internationally), to be superior to others, to operate under a monopoly, to secure a high market share, an appropriate level of income and a relatively high level of employment (Schwab \& Porter, 2007; Borowiecki \& Siuta-Tokarska, 2015; Borowski, 2015; Lotfi \& Karim, 2016)“. This is ,the ability to take action that provides stable, longterm development and contributes to the creation of market value and is understood as a determinant of development (Walczak, 2010)“. From the concept of competitiveness, its purpose is to create preconditions for learning and applying modern technologies in business (Yordan et al., 2017). In the context of globalization, the aim is to compete with the size of capital, the level of technical knowledge and the skills of specialists (Misala 2011; Żmuda \& Molendowski, 2016). This means that competitive advantage over other market players can be gained with more resources needed, acquiring new skills and knowledge.

At this article, the competitiveness of the company should be defined. The company's competitiveness is perceived as the ability to increase its market share in the production and sale of high-quality products or services for the relevant market. It is competition between entities for the level of customer/raw material market, labour force and level of the innovation apply. This can be achieved by minimizing costs, expanding the product range or focusing on the niche chosen (Borowiecki $\&$ Siuta-Tokarska, 2015). The better the company adapts to the market, the greater the market share. Adaptation is characterized by four elements of the company's competitiveness: competitiveness potential, competitive advantage, competitive instruments and competitive position (Walczak, 2010).

In economic terms, competition at company level is "a process where market participants, in pursuit of their own interests, try to make proposals that are more beneficial than others in terms of price, quality, delivery terms that affect decision making on transaction agreements (Borowiecki \& Siuta-Tokarska, 2015; Soelaksono, Sudiro, Rahayu, \& Sudjatno, 2018)". The application of competitive ability (competitive potential) by using the relevant competition instruments leads to the emergence of competitive advantage. Efforts are made to achieve the necessary competitive position (better international trade outcomes, better use of production factors and quantity-quality evolution) through improved competitiveness factors.

In this case, the competitiveness at the micro (company's) level is defined, where competition takes place between companies of the similar profile when competing for clients and aiming at efficient use of available internal potential (Schwab \& Porter, 2007). Competing companies have four possible options: to fight, to restrict competition, to avoid or ignore it. It is also necessary to distinguish the main types of competitiveness (Borowiecki \& Siuta-Tokarska, 2015):

1. Productivity-based competitiveness;

2. Investment-based competitiveness;

3. Innovation-based competitiveness;

4. Property-based competitiveness. 
These types of competitiveness reflect the topic at work that competitiveness depends on productivity (productive factor-based competitiveness), investment in innovation and innovative technologies (and their application in the process of operation) (investment and innovation-based competitiveness) and capital, wage and employment (because the capital that is available and used in the business process, the wages and the occupied/employed people are the assets). This is also complemented by key competitiveness theories: participation in competitiveness is based on participation in the world market, cost competitiveness theory based on costs, M. Porter's efficiency competitiveness theory based on efficiency (Borowski, 2015). In this case, the following factors are mentioned as essential aspects of competitiveness: institutional environment, macroeconomic situation, engineering infrastructure, which are purposefully managed for the overall growth of national competitiveness. In summary, competitiveness is a multifaceted category that can be analysed at different levels, but the article describes the competitiveness at the company level and its specification.

\subsection{Factors influencing the competitiveness}

Competitiveness is a kind of competition between service providers or producers of goods because they try to operate under the most favourable conditions, reduce the costs of research and increase the benefits. The ability to "fight" with competitors and overcome them depends on many internal and external factors. The impact of most internal and external factors on competitiveness has a more qualitative rather than a quantitative expression. Figure 1 shows the factors influencing competitiveness.

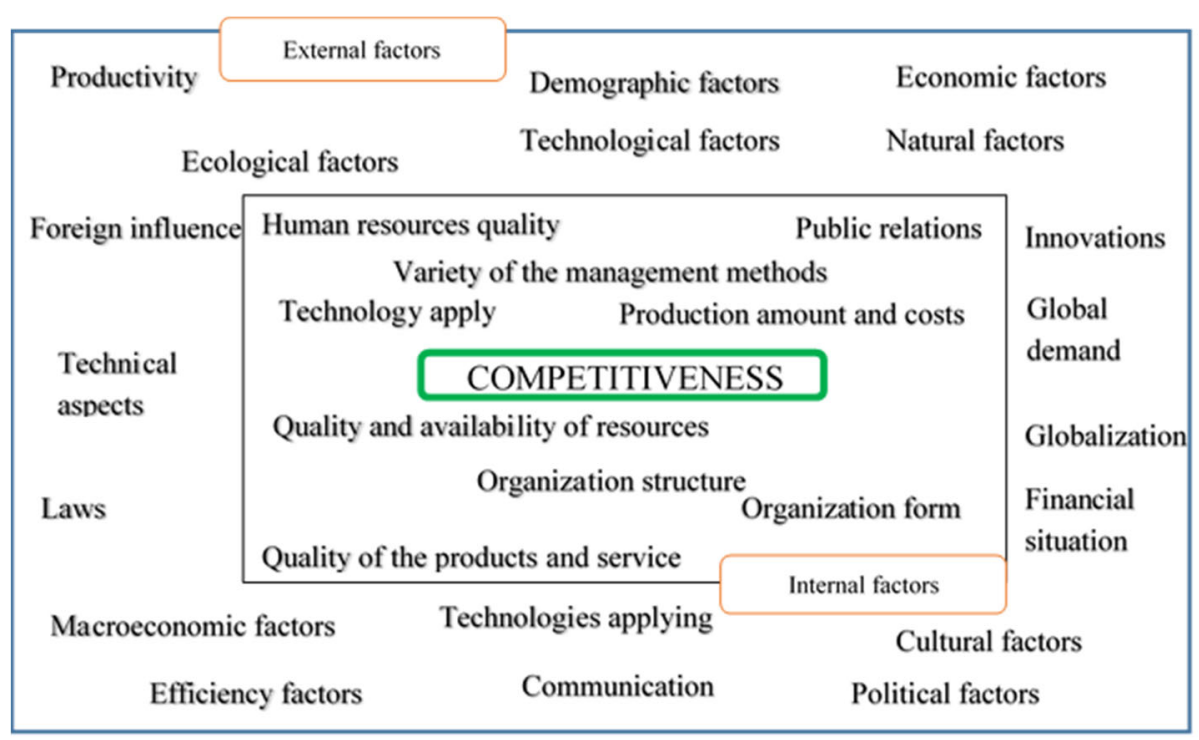

Figure 1. Factors influencing competitiveness (compiled by authors based on Borowiecki \& Siuta-Tokarska, 2015; Gołębiewski \& Podlińska, 2015; Wychowanek, 2015; Abreu-Novais et al., 2016; Lotfi \& Karim, 2016)

Figure 1 shows that all the factors that affect a country's competitiveness are divided into internal and external. Internal factors affect the country's competitiveness through the competitiveness of individual companies or industries. Internal activities can be divided into larger groups (Borowiecki \& Siuta-Tokarska, 2015; Gołębiewski \& Podlińska, 2015; Wychowanek, 2015): factors of human capital (human resources quality), the feature of products and services (quality and availability of resources, technology apply, production amount and costs), company's/industry features (organization form, variety of the management methods, public relations, organization structure). External factors is defined on a global scale and are divided into several groups (Borowiecki \& Siuta-Tokarska, 2015; Gołębiewski \& Podlińska, 2015; Wychowanek, 2015; Abreu-Novais et al., 2016; Lotfi \& Karim, 2016): productivity (through the improvement of work organization, positive changes in the quality of production factors, improvement of production process or efficient allocation of resources) and efficiency factors (quality of higher education, labour market efficiency, market size), political factors (laws, customs tariffs), trade liberalization (global demand) (possibility to choose foreign partners appropriately), foreign influence (foreign capital is a source of funds, creating a dynamic comparative advantage and investments stimulate the development of technological innovations and improve the productivity of factors), economic factors (macroeconomic stability, price level, understanding of competitor's behaviour, satisfaction of customer needs), demographic factors, technological and innovative factors (technological supply, level of business and innovation development), natural factors, cultural factors, globalization, ecological factors, technical aspects and financial situation.

Based on the correlation-regression analysis results, two of the above mentioned factors can be distinguished as the two most important factors that have the greatest impact on company's competitiveness - development of technological innovation (in a constantly changing environment it is important to keep up with technological innovation) and human resources 
(as society becomes more computerized and its importance remains). These factors are used for further assessment of companies (at a certain industry) competitiveness.

\section{The assessment of the industry's competitiveness}

The company's competitiveness is a complex, deeply analysed concept. Many scientists (Feurer \& Chaharbaghi, 1994; Herciu \& Ogrean, 2018) argue, that competitiveness is conditional and not absolute and therefore depends on the advantages of competitiveness, technology, value for shareholders and customers. Porter (2004) argues that company's competitiveness is a form of productivity because it defines the ability of companies to create added value from their core activity by using efficient methods and expressing that utility (Martinez Arroyo, Valenzo Jimenez \& Zamudio de la Cruz, 2017). C. L. Tan, Zailani, S. C. Tan, and Shaharudin (2016) complement this idea and claim that it is simply the ability to efficiently utilize the available resources to benefit themselves and better meet their customer's needs to increase their competitiveness. Because of this complexity and diversity, it is difficult to evaluate and define it.

Many authors (See Table 1) offer various methods to assess the competitiveness of different companies.

Table 1. Methods of the assessment of a company's competitiveness (source: compiled by the author based on literature review)

\begin{tabular}{|l|l|}
\hline \multicolumn{1}{|c|}{ Methods of the assessment } & \multicolumn{1}{c|}{ Authors of the sources (researchers) } \\
\hline Return On Equity & $\begin{array}{l}\text { Hafez, 2016; Martinez Arroyo, Valenzo Jimenez, \& Zamudio de la Cruz, 2017; Gushchina } \\
\text { \& Privalova, 2018; Kemunto Maroro, Gathii Kamau, \& Koima, 2018; Putri \& Nasution, } \\
\text { 2018; Ramlawati, Kusuma, \& Putra, 2018; Priyonoto, Wibowo \& Diarsyad, 2018; Soelak- } \\
\text { sono, Sudiro, Rahayu \& Sudjatno, 2018; Gupta \& Krishnamurti, 2019 }\end{array}$ \\
\hline Return On Assets & Hafez, 2016; Herciu \& Ogrean, 2018 \\
\hline Profitability ratio & $\begin{array}{l}\text { Bieniasz, 2016; Kemunto Maroro, Gathii Kamau, \& Koima, 2018; Putri \& Nasution, 2018; } \\
\text { Ramlawati, Kusuma \& Putra, 2018; Gupta \& Krishnamurti, 2019 }\end{array}$ \\
\hline Total factor productivity & $\begin{array}{l}\text { Martinez Arroyo, Valenzo Jimenez, \& Zamudio de la Cruz, 2017; Khokhlova, Kretova \& } \\
\text { Sergeev, 2018; Soelaksono, Sudiro, Rahayu, \& Sudjatno, 2018; Gupta \& Krishnamurti, } \\
\text { 2019 }\end{array}$ \\
\hline Revenues per employee & Herciu \& Ogrean, 2018; Khokhlova, Kretova, \& Sergeev, 2018 \\
\hline Dow Jones Sustainability Index & Herciu \& Ogrean, 2018 \\
\hline
\end{tabular}

Based on the literature review (Bieniasz, 2016; Martinez Arroyo, Valenzo Jimenez, \& Zamudio de la Cruz, 2017; Herciu \& Ogrean, 2018; Kemunto Maroro, Gathii Kamau, \& Koima, 2018; Khokhlova, Kretova, \& Sergeev, 2018; Putri \& Nasution, 2018; Ramlawati, Kusuma, \& Putra, 2018; Gupta \& Krishnamurti, 2019) it can be said that in assessing competitiveness it is important to evaluate three factors: productivity, efficiency and profitability. Herciu \& Ogrean (2018) suggests evaluating the competitiveness of company's by defining its utility, innovation and sustainability, but these concepts have no unified definition and can be viewed from different perspectives as well as having different meanings and aspects of evaluation, so it is necessary to assess the company's competitiveness using two main methods (Hafez, 2016; Martinez Arroyo, Valenzo Jimenez, \& Zamudio de la Cruz, 2017; Gushchina \& Privalova, 2018; Kemunto Maroro, Gathii Kamau, \& Koima, 2018; Putri \& Nasution, 2018; Ramlawati, Kusuma, \& Putra, 2018; Priyonoto, Wibowo, \& Diarsyad, 2018; Soelaksono, Sudiro, Rahayu, \& Sudjatno, 2018; Gupta \& Krishnamurti, 2019): return on equity (ROE) and total factor productivity (TFP) as the methods, that include the main indicators of economic stability assessment.

\section{Total factor productivity (TFP) and return on equity (ROE) as an expression of the assessment of competitiveness}

In order to accurately assess the economic activity of companies, it is suggested to apply different methods and one of the proposed and most suitable methods is the calculation of total factor productivity as an example of the analytical method. Competitiveness skills depends on management, strategic planning, investment, innovations, results of the company's activity and its competitiveness, therefore in order to improve the competitiveness of companies it is necessary to improve managerial skills and increase investments in innovations that help to compete with similar companies (Martinez Arroyo, Valenzo Jimenez, \& Zamudio de la Cruz, 2017; Soelaksono, Sudiro, Rahayu, \& Sudjatno, 2018).

Special scientists (Hulten, 2001; Kaliuzhnyi, 2003; Bernanke, Abel, \& Croushore, 2008; Van Beveren, 2010; Del Gatto, 2011; Chansarn, 2014; Lasagni, Nifo \& Vecchione, 2015; Puharts \& Kloks, 2015; Dhehibi, El-Shahat, Frija \& Hassan, 2016; Selçuk \& Köktas 2016; Spolador \& Roe, 2018; Gupta \& Krishnamurti, 2019) attention is given to the total factor productivity at macroeconomic researches. Labour productivity is one of the elements of total factor 
productivity, because total factor productivity is a measure of productivity and an important indicator of the political situation and a key driver of economic growth (Puharts \& Kloks, 2015) or a method of ,determining the contribution of capital, labour and total factor productivity to value-added growth“ (Kaliuzhnyi, 2003). TFP can also be understood as technical progress in a broad sense (Fassio, Kalantaryan, \& Venturini, 2015), which is closely related to human capital, innovation, infrastructure, taxes and regulatory frameworks (Cardarelli \& Lusinyan, 2015; Spolador \& Roe, 2018). If value added is high the shift from low to high productivity can lead to growth perspectives. The results show what components (capital or work) should be invested to increase productivity.

The growth of the overall productivity factor is a broader measure of innovation. Basically, innovation is "an idea, technique or object that is acceptable as an innovation approbation at a personal and national level" (Karafillis \& Papanagiotou, 2008), which shows the importance of innovation dynamics in the production process. Innovation is a multifaceted phenomenon and it is difficult to measure it. The dynamics of innovation are strictly technologically specific and differ from sector to sector, so here is the opportunity to use new knowledge to boost productivity growth. As a result, it is possible to produce new products in new ways and using technological innovations (Fassio et al., 2015).

TFP is part of the Cobb-Douglas production function (1) (Ferrante \& Freo, 2012; Filatovaite \& Bratčikovienè, 2015; Gupta \& Krishnamurti, 2019). The function of Cobb-Douglas most closely reflects the level of competitiveness of firms, because it includes the number of employees, resources and determinants of sales. So the Cobb-Douglas function (D‘Auria, Denis, Havik, Mc Morrow, Planas, Raciborski, Roger, \& Ross, 2010) reflects the value added (Y) as a combination of input factors - labour (L) and capital (K), overcapacity (UL, UK) and adjusted efficiency (EL, EK) (2).

$$
Y=\left(U_{L} L E_{L}\right)^{\alpha}\left(U_{K} K E_{K}\right)^{1-\alpha}=L^{\alpha} K^{1-\alpha} * T F P .
$$

Where:

$Y$ - value added;
$L$ - labour;
$K$ - capital;
$U L, U K$ - overcapacity;
$E L, E K$ - adjusted efficiency;
$T F P$ - total factor productivity.
Total factor productivity is defined on the basis by (2) equation (D‘Auria, et al., 2010).

$$
T F P=\left(E_{L}^{\alpha} E_{K}^{1-\alpha}\right)\left(U_{L}^{\alpha} U_{K}^{1-\alpha}\right) .
$$

It also includes a technological level and input factors are measured in physical units. However, on the basis of the total factor productivity, investments and their efficiency remain. The TFP trend is assessed by Solow balance using the Kalman filter method, which uses the link between the TFP cycle and capacity utilization. Solow residue (Spolador \& Roe, 2018) is calculated by predicting value added (or GDP), labour costs and capital reserves, which allow the extension of the TFP series using two additional notes. Since no forecast is applied, the model estimates two missing estimates and the TFP is based on the monitoring.

Labour resources are the numerical expression of a busy professional skilled staff. Efficiency depends mainly on how many people are employed in that sphere: if the organization has sufficient labour resources and rationally uses them, then a high level of productivity is achieved, production volumes increase and efficiency increases.

Productivity function shows the amount of output that can be obtained using the available amount of resources. Resources (production factors) may vary depending on the type of production. Most often, three groups of production factors are distinguished: work, capital and land. Since the land fund is virtually unchanged this factor is often not concluded in the production function.

Solow (1957) defined the total factor productivity as the efficiency with which companies available resources are translated into relevant outputs and have relevant results. At the sector level, the production function is detailed (3) (Van Beveren, 2010; Biddle, 2012; Lasagni et al., 2015).

$$
Y_{i t}=A_{i t} K_{i t}^{\alpha_{k}} L_{i t}^{\alpha_{l}} M_{i t}^{\alpha_{m}}
$$

where:

$Y_{i t}$ - the sector's revenue;

$A_{i t}$ - specific time-variant term;

$K_{i t}^{\alpha} k$ - our measure of physical capital, namely the value of tangible fixed assets as reported in the balance sheet;

$L_{i t}^{\alpha_{l}}-$ our measure of employment level;

$M_{i t}^{\alpha_{m}}$-raw materials expenditures. 
It follows that three factors - capital, labour and intermediate goods are included in the calculations. Scientists (Saliola \& Seker, 2011; Von Arnim \& Rada, 2011) offer to include the value of machines, the use of technological resources, the value of vehicles and equipment as a means of measuring capital, how work is valued by the total compensation of employees (wages) and intermediate goods are based on raw material and material prices. These factors lead to explanations of the factors of production, which "may be employed to create higher value-added and increase technical efficiency" (Baležentis, 2015; Carlsson, Messina, \& Nordström Skans, 2015). Observing these determinants can find suitable ways to increase their productivity (Chansarn, 2014).

By maximizing the benefits, a combination of work and capital is chosen that reduces the costs incurred and high expected profits (Zamparelli, 2015). The index includes three factors: value added, labour and capital. Productivity is measured in terms of value added (Šileika, Tamašauskienė, \& Bartelienè, 2010; Ranci, 2011). Value-added and its dynamic shows the changes in labour productivity depending on a number of factors (physical capital amount and quality, technology level, efficiency and flexibility in work organization and management) (Giroud \& Mueller, 2011; Gupta \& Krishnamurti, 2019). The economic downturn means lower profits and lower wages. Calculations require companies data on gross value added, average annual capital, use of fixed capital and average annual number of employees.

Another method of assessing the competitiveness of companies is the return of equity (ROE). Return on equity is a financial ratio, which shows how much the company earns in comparison with the total shareholder's equity invested in it or recorded in the balance sheet. ROE shows how many investors are recovering from their investments because if a business has a high capital turnover it will better manage its finances (Kemunto Maroro, Gathii Kamau \& Koima, 2018). ROE is also seen as a measurement of the results available to corporate executives from capital invested in a company that also influences capital structure (Putri \& Nasution, 2018). ROE is calculated using (4) equation (Hafez, 2016; Gushchina \& Privalova, 2018; Priyonoto et al., 2018).

$$
R O E=\frac{N I}{T E},
$$

where:

$R O E$ - return on equity;

$N I-$ net income after tax;

$T E$ - total equity (the book value of common equity).

It follows, net profit and equity data are also used in the calculation and evaluation of ROE, so this indicator includes a somewhat narrower range of companies' competitiveness assessment. Total factor productivity and Return on equity are calculated for Lithuania and Latvia applying some research limitations -here are analyzed the data (Eurostat, 2019) of the 2007-2017 y. y.

\section{The competitiveness assessment in the case of Lithuania and Latvia}

For the calculation of the total factor productivity and return on equity, the industry data are used. Here are marked the classification of the industries:

A - agriculture, forestry and fishing;

B to E - mining and quarrying; electricity, gas, steam and air conditioning supply; water supply, sewerage, waste management and remediation activities;

$\mathrm{C}$ - manufacturing;

F- construction;

$\mathrm{G}$ to $\mathrm{me}$ - wholesale and retail trade, repair of motor vehicles and motorcycles; transportation and storage; accommodation and food service activities;

$\mathrm{J}$ - information and communication;

$\mathrm{K}$ - financial and insurance activities;

$\mathrm{L}$ - real estate activities;

$\mathrm{M}$ to $\mathrm{N}$ - professional, scientific and technical activities; administrative and support service activities;

$\mathrm{O}$ to $\mathrm{Q}$ - public administration and defence, compulsory social security; education; human health and social work activities;

$\mathrm{R}$ to $\mathrm{U}$ - arts, entertainment and recreation; other service activities; activities of households as employers, undifferentiated goods- and services-producing activities of households for own use.

In this article, the modification of the production function - an analytical method is used. This method is used for the calculation of the factors influence the growth in value added. Using (2) equation the total factor productivity and using (4) equation return on equity for the period 2007-2017 years in Lithuania and Latvia are calculated. The results are shown in Figure 2 and 3. 


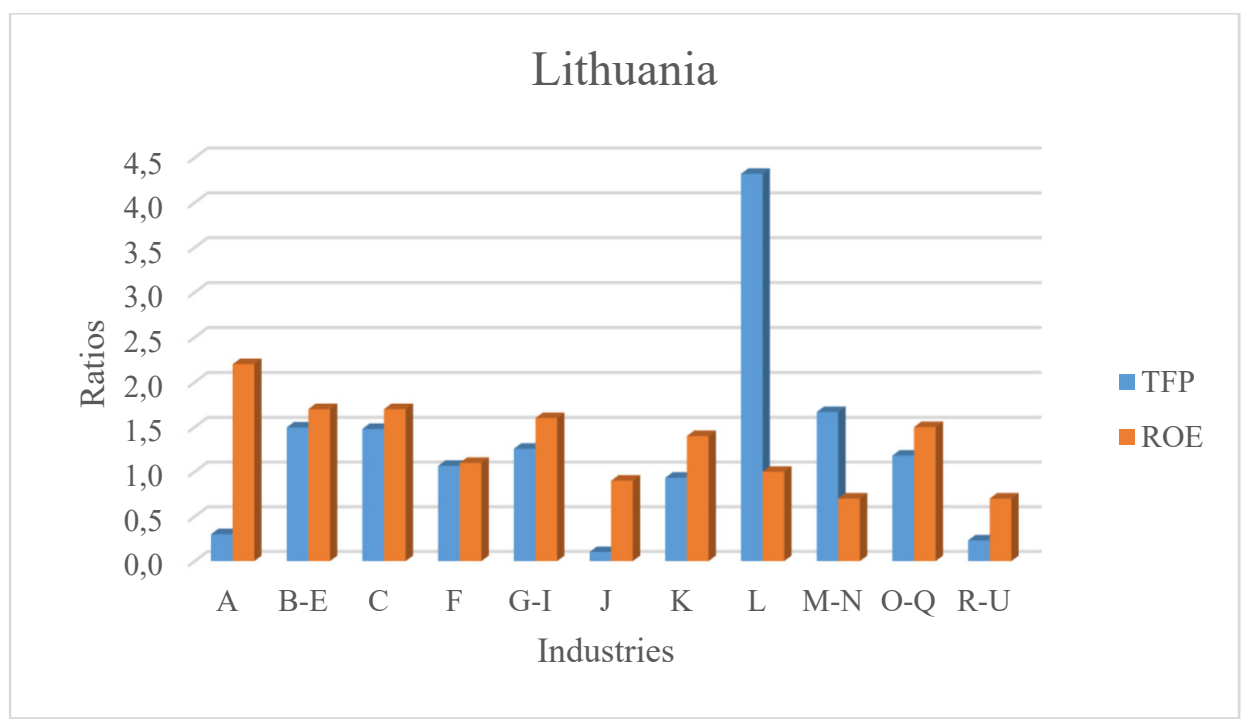

Figure 2. Total factor productivity and Return on equity 2007/2017 ratio in Lithuania (compiled by authors based on own calculations)

Figure 2 shows that the most productive industries in Lithuania using Total factor productivity method calculations results are: $\mathrm{L}$ (here total factor productivity from 2007 till 2017 increase 4,3 times), M-N (increase 1,7 times) and B-E and C (increase 1,5 times). At these sectors, human resources (employees) have a high level of qualification and all resources (especially technological innovations) are used. Using Return on equity method the most productive industries in Lithuania are: A (here return on equity from 2007 till 2017 increase 2,2 times), B-E and C (increase 1,7 times). It means that companies at these sectors earn in comparison with the total shareholder's equity invested in it are greater. Comparing these two methods it can be argued that the most productive sectors in Lithuania are mining and quarrying; electricity, gas, steam and air conditioning supply; water supply, sewerage, waste management and remediation activities; manufacturing. It follows, that companies at mentioned sectors are working productively and purposefully use its equity.

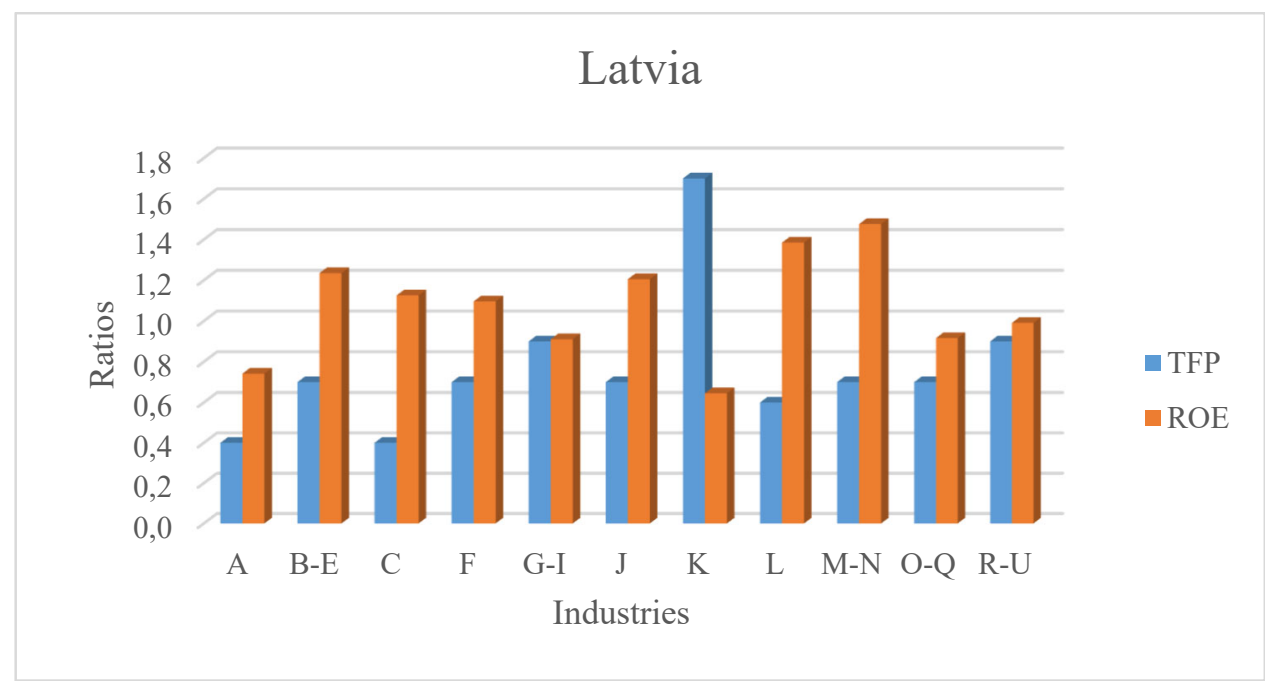

Figure 3. Total factor productivity and Return on equity 2007/2017 ratio in Latvia (compiled by authors based on own calculations)

Figure 3 shows that in Latvia using Total factor productivity method calculations results the most productive industries are: K (TFP from 2007 till 2017 increase 1,7 times), G-I and R-U (decrease 0,9 times). Using Return on equity method calculation results in Latvia the most productive industries are: M-N (ROE increase 1,5 times), L (increase 1,4 times), B-E and $\mathrm{J}$ (increase 1,2 times). It means that companies at these sectors earn in comparison with the total shareholder's equity invested in it are greater.

To sum up, in Lithuania the real estate activities and in Latvia - financial and insurance activities are very developed. Also, here is a link between the results of the competitiveness assessment using total factor productivity and return on equity in Lithuania. Here the most productive sectors are mining and quarrying; electricity, gas, steam and air conditioning supply; water supply, sewerage, waste management and remediation activities; manufacturing. But on the other 
hand in Latvia is no relation between the competitiveness assessment applying these two methods and it can be said, that relations between these methods are only available if companies have greater equity than other rates. Also, special attention should be given to other factors (like innovations or others).

\section{Conclusions}

Competitiveness is a multifaceted category that can be analyzed at different levels. Competitiveness at the company level is influenced by the two most important factors - development of technology and innovation (in a constantly changing environment it is important to keep up with technological innovation) and human resources (as the society becomes more computerized and its importance remains).

For the competitiveness assessment, it is important to evaluate three factors: productivity, efficiency and profitability. It follows, net profit and equity data are also used in the calculation and evaluation of ROE, so this indicator includes a somewhat narrower range of industries' competitiveness assessment. Total factor productivity and Return on equity are calculated for Lithuania and Latvia applying some research limitations - here are analyzed the data of the 2007-2017 y. y.

The results of the assessment competitiveness of industries in Lithuania using Total factor productivity method calculations result in are L (here total factor productivity from 2007 till 2017 increase 4,3 times), M-N (increase 1,7 times) and B-E and C (increase 1,5 times). At these sectors, human resources (employees) have a high level of qualification and all resources (especially technological innovations) are used. Using Return on equity method the most productive industries in Lithuania are: A (here return on equity from 2007 till 2017 increase 2,2 times), B-E and C (increase 1,7 times). It means that companies at these sectors earn in comparison with the total shareholder's equity invested in it are greater. Comparing these two methods it can be argued that the most productive sectors in Lithuania are mining and quarrying; electricity, gas, steam and air conditioning supply; water supply, sewerage, waste management and remediation activities; manufacturing. It follows, that companies at mentioned sectors are working productively and purposefully use its equity. Due to the assessment of industries productivity in Latvia using Total factor productivity method the most productive industries are: K (TFP from 2007 till 2017 increase 1,7 times), G-I and R-U (decrease 0,9 times). Using Return on equity method calculation results in Latvia the most productive industries are: M-N (ROE increase 1,5 times), L (increase 1,4 times), B-E and J (increase 1,2 times). It means that companies at these sectors earn in comparison with the total shareholder's equity invested in it are greater.

To sum up, in Lithuania the real estate activities and in Latvia - financial and insurance activities are very developed. Also, here is a link between the results of the competitiveness assessment using total factor productivity and return on equity in Lithuania. Here the most productive sectors are mining and quarrying; electricity, gas, steam and air conditioning supply; water supply, sewerage, waste management and remediation activities; manufacturing. But on the other hand in Latvia is no relation between the competitiveness assessment applying these two methods and it can be said, that relationship between these methods is only available if companies have greater equity than other rates. Also, special attention should be given to other factors (like innovations or others).

\section{References}

Abreu-Novais, M., Ruhanen, L., \& Arcodia, Ch. (2016). Destination competitiveness: what we know, what we know but shouldn't and what we don't know but should. Current Issues in Tourism, 19(6), 492-512. https://doi.org/10.1080/13683500.2015.1091443

Baležentis, T. (2015). The sources of the total factor productivity growth in Lithuanian family farms: a Färe-Primont index approach. Prague Economic Papers, 2, 225-241. https://doi.org/10.18267/j.pep.510

Bernanke, B. S., Abel, A. B., \& Croushore, D. (2008). Macroeconomics. 6th ed. Boston, MA: The Addison-Wesley. 672 p.

Biddle, J. (2012). Retrospectives: The introduction of the Cobb-Douglas regression. The Journal of Economic Perspectives, 26(2), 223-236. https://doi.org/10.2307/41495312

Bieniasz, A. (2016). Determinanty rentowności kapitału własnego banków spółdzilczych w Polsce. Journal of Agribusiness and Rural Development, 1(39), 17-24. https://doi.org/10.17306/JARD.2016.2

Bondarenko, S., Liganenko, I., Kalaman, O., \& Niekrasova, L. (2018). Comparison of methods for determining the competitiveness of enterprises to determine market strategy. International Journal of Civil Engineering and Technology, 9(13), 890-898.

Borowiecki, R., \& Siuta-Tokarska, B. (2015). Konkurencyjność przedsiębiorstw i konkurencyjność gospodarki Polski - zarys problemu. Nierówności Spoleczne a Wzrost Gospodarczy, 41(1), 52-66.

Borowski, J. (2015). Koncepcje teoretyczne konkurencyjności międzynarodowej. Optimum. Studia ekonomiczne, 4(76), 25-42. https://doi.org/10.15290/ose.2015.04.76.02

Bruneckienè, J., \& Kilijonienè, A. (2011). Lietuvos regionų konkurencingumo klasterinè analizè. Management theory and studies for rural business and infrastructure development, 25(1), 60-69.

Cardarelli, R., \& Lusinyan, L. (2015). U. S. Total factor productivity slowdown: evidence from the U. S. States. IMF Workin Paper, 15(116), 1-24. https://doi.org/10.5089/9781513520834.001 
Carlsson, M., Messina, J., \& Nordström Skans, O. (2015). Wage adjustment and productivity shocks. The Economic Journal, 253, 1-35. https://doi.org/10.1111/ecoj.12214

Chansarn, S. (2014). Total factor productivity of commercial banks in Thailand. International Journal of Business and Society, $15(2), 215-234$.

Croes, R. (2011). Measuring and explaining competitiveness in the context of small island destinations. Journal of Travel Research, 50(4), 431-442. https://doi.org/10.1177/0047287510368139

D‘Auria, F., Denis, C., Havik, K., Mc Morrow, K., Planas, Ch., Raciborski, R., Roger, W., \& Rossi, A. (2010). The production function methodology for calculating potential growth rates and output gaps. Economic Papers, 420, 1-107.

Del Gatto, M., Di Liberto, A., \& Petraglia, C. (2011). Measuring productivity. Journal of Economic Surveys, 25(5), 952-1008. https://doi.org/10.1111/j.1467-6419.2009.00620.x

Dhehibi, B., El-Shahat, A. A. I. A., Frija, A., \& Hassan, A. A. (2016). Growth in total factor productivity in the Egyptian agriculture sector: growth accounting and econometric assessments of sources of growth. Sustainable Agriculture Research, 5(1), 38-48. https://doi.org/10.5539/sar.v5n1p38

Eurostat. (2019). Indicators. Retrieved from http://ec.europa.eu/eurostat

Fassio, C., Kalantaryan, S., \& Venturini, A. (2015). Human resources and innovation: total factor productivity and foreign human capital. IZA Discussion Paper, 9422, 1-33. https://doi.org/10.2139/ssrn.2631086

Ferrante, M. R., \& Freo, M. (2012). The total factor productivity gap between internationalised and domestic firms: net premium or heterogeneity effect?. The World Economy, 35(9), 1186-1214. https://doi.org/10.1111/j.1467-9701.2011.01415.x

Feurer, R., \& Chaharbaghi, K. (1994). Defining competitiveness: a holistic approach. Management Decision, 32(2), 49-58. https://doi.org/10.1108/00251749410054819

Filatovaitè, D., \& Bratčikovienè, N. (2015). Modelling of production relations in the Lithuanian economy. Lithuanian Journal of Statistics, 54(1), 52-60.

Giroud, X., \& Mueller, H. (2011). Corporate governance, product market competition, and equity prices. Journal of Finance, 66, 563-600. https://doi.org/10.1111/j.1540-6261.2010.01642.x

Gołębiewski, J., \& Podlińska, O. (2015). Determinanty konkurencyjności Polskich regionów w Unii Europejskiej. Przegląd zachodniopomorski, $X X X$ (LIX)2, 7-20. https://doi.org/10.18276/pz.2015.2-01

Gupta, K., \& Krishnamurti, Ch. (2019). Corporate social responsibility, competition, and firm value. SSRN Electronic Journal, 1-45. https://doi.org/10.22495/jgr_v5_i4_p3

Gushchina, E. Y., \& Privalova, O. Y. (2018). The significant factors in the decomposition of ROE of the companies in the extractive sector. Economics and Management: Problems and Innovations, 17-23.

Hafez, H. M. (2016). Corporate social responsibility and firm value: an empirical study of an emerging economy. Journal of Governance and Regulation, 5(4), 40-53. https://doi.org/10.22495/jgr_v5_i4_p3

Herciu, M., \& Ogrean, C. (2018). Business sustainable competitiveness - a synergistic, long-run approach of a company's resources and results. Studies in Business and Economics, 13(3), 26-44. https://doi.org/10.2478/sbe-2018-0033

Hulten, Ch. R. (2001). New developments in productivity analysis. University of Chicago Press. 632 p. https://doi.org/10.7208/chicago/9780226360645.001.0001

Kaliuzhnyi, V. V. (2003). Teoriia i metody faktornogo analiza ekonomicheskogo rosta. Ekonomicheskaia kibernetika. Mezhdunarodnyi nauchnyi zhurnal, 3-4, 21-22.

Karafillis, C. C., \& Papanagiotou, E. (2008). The contribution of innovations in total factor productivity of organic olive enterprises. 12 th Congress of the European Association of Agricultural Economists, 1-10.

Kemunto Maroro, R., Gathii Kamau, J., \& Koima, J. (2018). Effect of asset restructuring on return on equity of financially distressed commercial banks in Kenya. International Journal of Business Management and Processes (IJBMP), 3(2), 26-39.

Khokhlova, G., Kretova, N., \& Sergeev, V. (2018). Competitiveness as a factor of the company's investment attractiveness. MATEC Web of Conferences, 212, 1-6. https://doi.org/10.1051/matecconf/201821208019

Lasagni, A., Nifo, A., \& Vecchione, G. (2015). Firm productivity and institutional quality: evidence from Italian industry. Journal of Regional Science, 55(5), 774-800. https://doi.org/10.1111/jors.12203

Lotfi, B., \& Karim, M. (2016). Competitiveness determinants of Moroccan exports: quantity-based analysis. International Journal of Economics and Finance, 8(7), 140-148. https://doi.org/10.5539/ijef.v8n7p140

Martinez Arroyo, J. A., Valenzo Jimenez, M. A., \& Zamudio de la Cruz, A. G. (2017). Measurement and analysis to improve competitiveness. Memoria del XI Congreso de la Red Internacional de Investigadores en Competitividad; noviembre 2017, 765-783.

Meilienė, E., \& Snieška, V. (2010). Lietuvos pramonės konkurencingumo veiksniai eksporto politikos nuostatose. Viešoji politika ir administravimas, 31, 119-132.

Misala, J. (2011). Międzynarodowa konkurencyjność gospodarki narodowej. PWE: Warszawa. 306 p.

Porter, M. E. (2004). Building the microeconomic foundations of prosperity: Findings from the business competitiveness index. World Competitiveness Report, 2005.

Priyonoto, B., Wibowo, A. S., \& Diarsyad, M. I. (2018). Pengaruh current ratio, debt to equity ratio, return on equity terhadap return saham pada perusahaan consumer goods di Bursa Efek Indonesia. Jurnal Riset Akuntansi Going Concern, 14(1), $214-224$. https://doi.org/10.13140/RG.2.2.23901.87529

Puharts, A., \& Kloks, P. (2015). Sources of TFP growth in the Baltic states: the frontier approach. SSE Riga student research papers, $4(169), 1-42$. 
Putri, L. P., \& Nasution, A. J. P. (2018). The effect of return on equity and sales growth to debt to equity ratio in corporate sector advertising, printing and media in Indonesia. The 11th International Workshop and Conference of Asean Studies in Linguistics, Islamic and Arabic Education, Social Sciences and Educational Technology 2018, 633-638. https://doi.org/10.31227/osf.io/3qp4g

Ramlawati, \& Kusuma Putra, A. H. P. (2018). Total quality management as the key of the company to gain the competitiveness, performance achievement and consumer satisfaction. International Review of Management and Marketing, 8(4), 60-69.

Ranci, C. (2011). Competitiveness and social cohesion in Western European cities. Urban Studies, 1-16. https://doi.org/10.1177/0042098010394688

Saliola, F., \& Seker, M. (2011). Total factor productivity across the developing world. Enterprise surveys country note series, 23, $1-8$.

Schwab, K., \& Porter, M. E. (2007). The Global Competitiveness Report 2007-2008. World Economic Forum: Geneva, Switzerland. $519 \mathrm{p}$.

Selçuk, I. S., \& Köktas, A. M. (2016). Energy market regulations and productivity: an examination on OECD countries between the years of 1975-2007. Sosyoekonomi, 24(27), 243-261. https://doi.org/10.17233/se.13369

Soelaksono, T., Sudiro, A., Rahayu, M., \& Sudjatno. (2018). The influence of capability managerial on competitiveness of the company through the planning strategy, investment, innovation and performance of the company (a study on corporate manufacturing industry group B medium sized territory Gerbang Kertosusila, East Java). International Review of Management and Marketing, 8(2), 22-32.

Solow, R. M. (1957). Technical change and the aggregate production function. The review of Economics and Statistics, 39(3), 312320. https://doi.org/10.2307/1926047

Spolador, H., \& Roe, T. (2018). The agriculture TFP growth and labour allocation in the Brazilian economy, 2018 Conference, July 28-August 2, 2018, Vancouver, British Columbia, 1-23.

Šileika, A., Tamašauskienė, Z., \& Bartelienè, N. (2010). Comparative analysis of wages and labour productivity in Lithuania and other EU-15 countries. Socialiniai tyrimai, 3(20), 132-143.

Tan, C. L., Zailani, S. H. M., Tan, S. C., \& Shaharudin, M. R. (2016). The impact of green supply chain management practices on firm competitiveness. International Journal of Business Innovation and Research, 11(4), 539-558. https://doi.org/10.1504/IJBIR.2016.079507

Tarkowski, M., Palmowski, T., Kopeć, K., \& Wendt, J. A. (2016). Gdynia w Unii Europejskiej: konkurencyjność gospodarki. Uniwersytet Gdański. Wydawnictwo „Bernardinum”: Gdańsk-Pelplin. 203 p.

Van Beveren, I. (2010). Total factor productivity estimation: a practical review. Journal of Economic Surveys, 26(1), 98-128. https://doi.org/10.1111/j.1467-6419.2010.00631.x

Von Arnim, R., \& Rada, C. (2011). Labour productivity and energy use in a three-sector model: an application to Egypt. Development and Change, 42(6), 1323-1348. https://doi.org/10.1111/j.1467-7660.2011.01741.x

Walczak, W. (2010). Analiza czynników wpływających na konkurencyjność przesiębiorstw. e-mentor, 5, 5-12.

Wychowanek, J. (2015). Tradycja w aspekcie budowania konkurencyjności małego przedsiębiorstwa. Prace naukowe Uniwersytetu Ekonomicznego we Wrocławiu, 401, 601-613. https://doi.org/10.15611/pn.2015.401.55

Yordan, A., Nasution, A. S., \& Buang, N. A. (2017). The level of global competitiveness and personal level development of aceh handicraft entrepreneurs. Science, Engineering and Social Science Series, 1(1), 1-6.

Zamparelli, L. (2015). Induced innovation, endogenous technical change and income distribution in a labor-constrained model of classical growth. Metroeconomica, 66(2), 243-262. https://doi.org/10.1111/meca.12068

Żmuda, M., \& Molendowski, E. (2016). W poszukiwaniu istoty konkurencyjności gospodarki narodowej: studium interdyscyplinarne. Finanse, Rynki Finansowe, Ubezpieczenia, 3(81), 323-333. https://doi.org/10.18276/frfu.2016.81-28 